\title{
Effect of Work Environment and Transformational Leadership Style on Employee Performance of PT. Excelso Multi Rasa Outlet at Tunjungan Plaza Surabaya
}

\author{
$1^{\text {st }}$ Ika Prasetya Utami ${ }^{1}, 2^{\text {nd }}$ Drs. Ec. I Nyoman Sudapet,MM ${ }^{2}, 3^{\text {rd }}$ Hamzah Denny Subagio, SE., MM ${ }^{3}$ \\ Narotama University, Surabaya, Indonesia \\ ikaprasetyautami21@gmail.com
}

\begin{abstract}
This study aims to determine the effect of simultaneous and partial work environment and transformational leadership style on improving the performance of employees of PT. Excelso Multi Rasa Outlet at Tunjungan Plaza Surabaya. This research is quantitative research. Population and sample based on questionnaire distribution to employees of PT. Excelso Multi Rasa Outlet in Tunjungan Plaza Surabaya was taken as many as 45 respondents. Data collection techniques using interviews, observation and questionnaires. The data analysis used is reliability test, validity test, classic assumption test and multiple linear analysis test. The results of the study simultaneously and partially the work environment and transformational leadership style have a significant effect on the performance of employees of PT. Excelso Multirasa Outlet at Tunjungan Plaza Surabaya because of its significance $<0.005$

Keywords: Work Environment, Transformational Leadership Style, Employee Performance.
\end{abstract}

\section{INTRODUCTION}

The development of the business world in Indonesia that is increasingly developing requires more changes in business practices. Changes made in accordance with certain objectives so that organizations that run business in accordance with expectations and able to improve company performance. Facing an increasingly competitive competition situation, making companies need resources that are facilitated to survive and develop their business. One of the food and beverage businesses currently being developed is Cafe Excelso. The first Cafe Excelso was opened in 1991 at Plaza Indonesia, Jakarta. To support the new coffee brand made by PT. Santos Jaya Abadi at that time, namely Kopi Excelso. caffe Excelso is made and marketed in the form of coffee by reason of fulfilling the needs of middle and upper class coffee and eliminating the image of mixed coffee. The best quality coffee is still in the form of seeds and pounded fresh if you want to brew it, so it feels really good. Café Excelso was established to support marketing and images made for Excelso coffee. By choosing the upper middle class market, Excelso coffee can only be found in certain supermarkets and at Cafe Excelso itself. In this study, the authors conducted a survey in advance of the company at Excelso outlets in Tunjungan Plaza Surabaya by conducting interviews and asking for secondary data to the head of employees of PT. Excelso Multirasa Outlet at Tunjungan Plaza Surabaya, where from the survey results that have high competence but cannot develop high performance in a job, this is possible due to factors in the work environment. The leadership model developed by transformational leaders is expected to increase subordinates to achieve optimal work results. Based on the observation of the author, supervisors in Excelso at Tunjungan Plaza Surabaya put different pressure on their subordinates to compile assignments that improve employee performance also increased. Lack of supervision in the development of employee promotions. Based on the description above, it can be seen about the importance of the work environment, transformational leadership style to improve employee performance. If an environment can run conducively, then employee performance will increase. Company goals will be easily achieved 


\section{BASIC THEORY}

Work Environment (X1)

Work environment is the entire tooling equipment and materials faced, the surrounding environment in which a person works, the method of work, and work arrangements both as individuals and as a group [1]. The indicators used in this study are:

1. Enough lighting[1]

2. Awake air circulation[1]

3. Good cleanliness [1]

4. Complete office equipment ([1]

5. Secure work security [1]

6. Relations between fellow colleagues [1]

7. Work relationship between boss and subordinate [1]

Transformational Leadership (X2)

Transformational leadership is a leader who devotes his attention to the problems faced by each of his followers and the development needs of each of his followers by giving enthusiasm and encouragement to achieve his goals (Stephen P Robbins, 2007) in [2]. The indicators used in this study are as follows:

1. Idealized influence (Brown and Keeping, 2005) in [2]

2. Inspiration motivation (Brown and Keeping, 2005) in [2]

3. Intelectual stimulation (Brown and Keeping, 2005) in [2]

4. Individulized consideration (Brown and Keeping, 2005) in [2].

\section{Performance (Y)}

Performance is the quantity or quality of something produced or services provided by someone who does the work Luthans (2005) in Bintoro end Daryanto (2017). the indicators used in this study are:

1. Kualitas (Robins, 2006) in [4]

2. Kuantitas (Robins, 2006) in [4]

3. Ketepatan waktu (Robins, 2006) in [4]

4. Efektivitas (Robins, 2006) in [4]

5. Kemandirian (Robins, 2006) in [4]

\section{CONCEPTUAL FRAMEWORK}

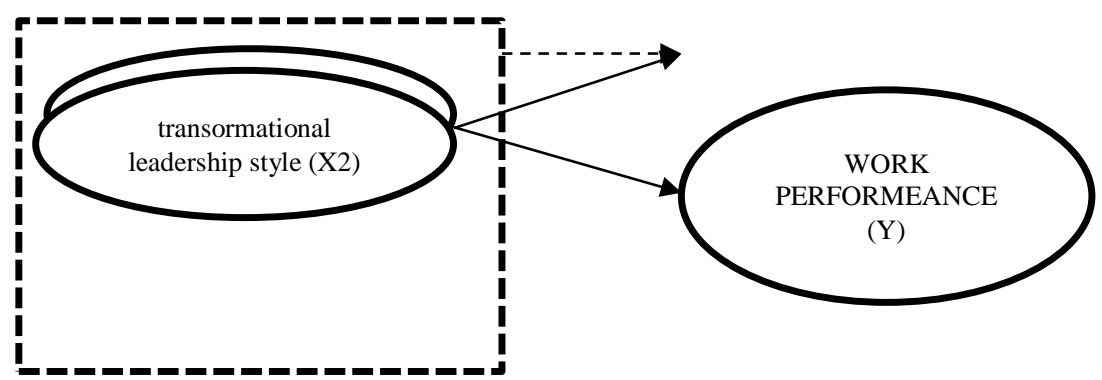

Figure 1 : Conceptual research framework

\section{HYPOTHESIS}

The hypothesis is a temporary answer to the research problem, until proven through the collected data (Sugiyono, 2010). A hypothesis will be accepted if the data collected supports the statement. The hypothesis is a basic assumption which then makes a theory that still has to be tested for its truth. So the hypothesis is a temporary answer to the statements expressed in the formulation of the problem. The hypothesis that the authors propose in this study are:

1. Work environment and transformational leadership style simultaneously on the performance of employees of PT. Excelso Multi Rasa Outlet at Tunjungan Plaza Surabaya. 
2. The work environment is partial to the performance of employees of PT. Excelso Multi Rasa Outlet at Tunjungan Plaza Surabaya.

3. Transformational leadership style partially on the performance of employees of PT. Excelso Multi Rasa Outlet at Tunjungan Plaza Surabaya.

\section{RESEARCH METHOD}

Research uses a quantitative approach is a method based on the philosophy of positivism, used to examine the population or a particular sample, data collection using research instruments, data analysis is quantitative / statistical, with the aim of testing what has been set (Sugiyono, 2016) This research variable consisted of independent variables Work Environment, Transformational Leadership Style. And the variable dependent Employee Performance.. The population in this study were employees of PT. Excelso Multi Rasa Outlet in Tunjungan Plaza Surabaya was taken as many as 45 respondents. The data The analysis Multiple Linear Regression spss 16.0 software.

\section{RESULT AND DISCUSSION}

\begin{tabular}{|c|c|c|c|c|c|}
\hline \multicolumn{6}{|c|}{ Coefficients ${ }^{\mathrm{a}}$} \\
\hline \multirow[t]{2}{*}{ Model } & Unstandardize & Coefficients & Standardized & $\mathrm{T}$ & Sig. \\
\hline & B & Std. Error & Beta & & \\
\hline (Constant) & -.022 & .277 & & -.079 & .937 \\
\hline $\mathrm{X} 1$ & .715 & .107 & .673 & 6.703 & .000 \\
\hline $\mathrm{X} 2$ & .228 & .092 & .248 & 2.469 & .018 \\
\hline
\end{tabular}

Data : Output Spss versi 16.0

\section{Effect of the work environment on employee performance}

The results of statistical calculations show that the value of tcount of 6.703 with sig 0,000 is smaller than 0.05 then $\mathrm{H} 0$ is rejected means that the work environment has a significant effect partially on employee performance.

This means that the working environment conditions owned by PT. Excelso Multi Rasa Outlet in Tunjungan Plaza Surabaya affect employee performance as indicated by the ability of employees to complete work. This is proven according to the opinion of Hamali, (2016) which states that employees will be able to carry out their activities well, so that an optimal outcome is achieved, if one of them is supported by an appropriate environmental condition.

\section{Effect of Leadership Style on Employee Performance}

The results of statistical calculations show that the value of tcount is 2.469 with sig 0.018 smaller than 0.05 , then $\mathrm{H} 0$ is rejected, meaning that the transformational leadership style has a partially significant effect on employee performance.

PT. Excelso Multi Rasa Outlet leaders at Tunjungan Plaza Surabaya will motivate subordinates to do better than what can be done, in other words can increase the trust or confidence of subordinates who will influence the increase in performance so that the target set by the company is achieved proven in accordance with the opinion of Tohardi (2010: 207) that the success or failure of the leader is determined by the style of attitude and action that appears from being able to listen, communicate, make decisions and motivate subordinates. 


\section{CONCLUSIONS AND RECOMMENDATIONS}

\begin{tabular}{llrrrrr}
\hline \multirow{2}{*}{ Model } & \multicolumn{3}{c}{ ANOVA $^{\mathbf{b}}$} & & \\
& & Sum of Squares & df & Mean Square & F & Sig. \\
\hline $1 \quad$ Regression & 18.635 & 2 & 9.318 & 44.598 & $.000^{\mathbf{a}}$ \\
& Residual & 8.775 & 42 & .209 & \\
& Total & 27.410 & 44 & & \\
a. Predictors: (Constant), X2, X1 & & & & \\
b. Dependent Variable: Y & & & & \\
\hline
\end{tabular}

Data : Output Spss versi 16.0

Based on the analysis that has been done, some conclusions can be drawn as follows:

1) In fact, the analysis of the physical status of people who have been diagnosed or not, is due to the value of health in the work environment (X1) and transformational leadership style (X2) at 44.598 with sig scores. at $0,000<\alpha=0.05$. This shows that the work environment and transformational leadership style are also very significant, especially in the workforce. So that the first hypothesis is proven to be true

2) In fact, the analysis of the linear damage that has been done, but due to the value of the performance of the working environment $(\mathrm{X} 1)$ as 0.431 is positive with the value of the sig. 0,000 more than $\alpha$ 0.05. For this reason, the work environment has a significant impact on patients, even though the work environment is very high. So theo second hypothesis is proven true

3) In fact, the analysis of the linear status of people who have been visited, but due to the value of performance of the transformational leadership style (X2) as 0.424 is positive with a score of sig. 0,000 more than $\alpha 0.05$. For this reason, the work environment has a significant impact on patients, even though the work environment is very high. So that the third hypothesis proved the truth

\section{LIMITATIONS}

In this study to avoid extensive discussion and not lead to research objectives, this study is limited to the influence of the work environment and transformational leadership style on the performance of PT. Excelso Multi Rasa Outlet employees at Tunjungan Plaza Surabaya, if there are other independent variables used to measure performance employees, the independent variables were not discussed in this study.

\section{REFERENCES}

[1] Sedarmayanti, Sumber Daya Manusia dan Produktivitas Kerja. Bandung: Mandar Maju, 2001.

[2] D. Sudaryono, Pengantar Manajemen: Teori dan Kasus. 2017: CAPS (Center for Academic Publishing Service), 2017.

[3] M. J. Arnold dan K. E. Reynolds, "Hedonic shopping motivations," J. Retail., 2003.

[4] M. . Bintoro, Manajemen Penilaian Kinerja Karyawan. Yogyakarta: Penerbit Gaya Media, 2017.

[5] Prof. Dr sugiyono, Metode Penelitian Kuantitatif Kualitatif Dan R\&D. Bandung: Alfabeta, Bandung, 2008. 